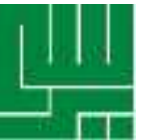

\title{
Hubungan Invasi Miometrium dengan Invasi Limfovaskular dan Grade Histologik pada Karsinoma Endometrium
}

\section{Correlation Miometrial Invasion with Limfovascular Invasion and Histologic Grade in Endometrial Carcinoma}

\author{
Shintia Christina ${ }^{1}$, Chandra Kartika Setyaningsih², \\ Puspa Pelita Sukma Hermawan ${ }^{3}$ \\ ${ }^{1}$ Department of Pathology, FKIK UKRIDA \\ 2Department of Anatomical Pathology, FKIK UKRIDA \\ 3Student Faculty of Medicine, FKIK UKRIDA
}
KATA KUNCI Karsinoma endometrium, invasi miometrium, invasi limfovaskular, derajat histologik
KEYWORDS Endometrial carcinoma, myometrial invasion, lymphovascular invasion, histologic grading

Karsinoma endometrium menduduki urutan keenam kanker pada wanita. Faktor prediktor prognosis pada karsinoma endomerium adalah grade histologik, invasi miometrium dan invasi limfovaskular. Kejadian metastasis kelenjar getah bening melalui limfovaskular pada karsinoma endometrium meningkat dengan adanya invasi tumor ke miometrium yang lebih dalam. Pada penelitian ini ingin diketahui apakah invasi miometrium mempunyai hubungan dengan invasi limfovaskular dan grade histologik. Apakah semakin tinggi grade histologik maka kejadian invasi miometrium dan invasi limfovaskular semakin meningkat.

Penelitian analitik kategorik tidak berpasangan dan retrospektif dengan menilai ulang slide histopatologik pada karsinoma endometrium di RSUD Tarakan. Penilaian ulang meliputi grade histologik, invasi miometrium dan invasi limfovaskular.

Didapatkan hubungan yang bermakna antara invasi miometrium dengan kejadian invasi limfovaskular $(p=0,029)$. Hubungan derajat histologik dengan kejadian invasi miometrium dan invasi limfovaskular didapatkan tidak bermakna pada penelitian ini.

Semakin tinggi grade histologik tidak meningkatkan kemungkin invasi ke miometrium maupun invasi limfovaskular, sedangkan invasi ke miometrium yang lebih dari setengah ketebalan miometrium meningkatkan kemungkinan adanya invasi limfovaskular yang berarti meningkatkan risiko metastasis. 
ABSTRACT Endometrial carcinoma is a fairly common malignancy represents $4.8 \%$ of 670,587 female malignancy cases in Southeast Asia. The incidence of lymph node metastases in endometrial carcinoma increase from $3 \%$ to $46 \%$ when tumor invades more than half of the depth of myometrium layer.

To determine the association between myometrial invasion in endometrial carcinoma with lymphovascular invasion and histologic grade.

The study objects were histopathological data and slides of endometrial carcinoma that has been examined by hysterectomy in RSUD Tarakan. Once the data is fully collected, the histopathological slide was assessed each case by microscopic evaluation. The final data is processed using statistical program SPSS and Microsoft Excel.

A significant association was found between myometrial invasion in endometrial carcinoma with lymphovascular invasion ( $p=0.029)$. Meanwhile, the association of histologic grades with the incidence of myometrial invasion and lymphovascular invasion were not significant through this study.

The incidence of tumor invasion $\geq 50 \%$ myometrial depth has a greater likelihood to the occurrence of lymphovascular invasion in this study. Thus, definitive total hysterectomy therapy is needed for the exact diagnosis in pathologic staging of endometrial carcinom.

\section{PENDAHULUAN}

\section{Latar Belakang}

Karsinoma endometrium merupakan keganasan yang paling sering terjadi pada masalah ginekologis selain kanker ovarium dan kanker serviks. Karsinoma yang terjadi pada dinding rahim ini umumnya dijumpai pada wanita pasca menopause dan jarang terjadi pada wanita dibawah 40 tahun. (Bieber et al., 2015) Berdasarkan data statistik The American Cancer Society (ACS) tahun 2010-2014, angka kejadian karsinoma endometrium menempati urutan kelima setelah kanker payudara, prostat, paru, dan kolorektal. Sekitar 39.000 wanita per tahunnya terdiagnosa karsinoma endometrium di Amerika Serikat, dengan total 7.400 kasus kematian per tahun. Sedangkan, insiden karsinoma endometrium di wilayah Asia Tenggara, sebesar 4,8\% dari 670.587 kasus keganasan pada wanita (Society, Hurt et al., 2011). Karsinoma endometrium dapat terjadi pada wanita yang belum mengalami menopause $(25 \%)$ maupun wanita pascamenopause (75\%).

Correspondence :

Shintia Christina, Department of Pathology, FKIK UKRIDA

Email : shintia.christina@ukrida.ac.id 
Kelompok terbesar yang umumnya ditemukan menderita karsinoma endometrium adalah kelompok usia 50-59 tahun, dengan 5$10 \%$ kasus terdiagnosis pada pasien usia kurang dari 40 tahun (Callahan and Caughey, 2009). Gejala klinis yang ditemukan pada pasien biasanya berupa perdarahan pascamenopause. Perdarahan yang tidak berhubungan dengan siklus menstruasi (perimenopausal menometrorrhagia) menjadi salah satu gejala klinis pada pasien usia sebelum menopause. Faktor risiko karsinoma endometrium adalah obesitas, anovulasi kronik, nullipara, menopause yang terlambat, penggunaan estrogen eksogen, hipertensi, riwayat penggunaan tamoxifen dan diabetes mellitus. Selain itu, lebih dari 50\% Lynch II syndrome akan berkembang menjadi karsinoma endometrium dengan atau tanpa karsinoma ovarium sebelum berkembang menjadi kanker kolon. Sehingga, pasien yang memiliki riwayat familial penyakit tersebut hendaknya dilakukan biopsi per tahunnya pada awal usia 35 tahun (Callahan and Caughey, 2009; DiSaia et al., 2018)

Berdasarkan patogenesisnya, karsinoma endometrium dibagi menjadi dua yaitu tipe I dan tipe II. Karsinoma endometrium tipe I merupakan tipe yang paling sering ditemukan $(80 \%)$ dengan penderita dengan riwayat paparan esterogen kronik. Tipe ini biasanya diawali dengan hiperplasia endometrium yang atipikal dan berkembang menjadi karsinoma. Karsinoma endometrium tipe II sebaliknya, tipe ini tidak berhubungan dengan paparan esterogen dan tidak diawali dengan hiperplasia endometrium (Callahan and Caughey, 2009; DiSaia et al., 2018).

Karsinoma endometrium yang termasuk ke dalam tipe I yaitu karsinoma endometrioid dan musinosum. Sedangkan karsinoma serosum, sel jernih, dan karsinoma endometrium yang tidak terdiferensiasi digolongkan ke dalam tipe II. Karsinoma endometrioid merupakan jenis karsinoma endometrium yang sering terjadi yaitu sekitar $80 \%$ kasus. Dengan tumor non-endometrioid lain yang dapat ditemukan yaitu, karsinoma musinosum (5\%), karsinoma clear cell $(5 \%)$, karsinoma serosum papiler (4\%). Meskipun jarang terjadi, tipe non-endometrioid ini cenderung memiliki pertumbuhan yang lebih agresif. Adenokarsinoma yang invasif biasanya terjadi akibat proliferasi dari sel-sel glandular endometrium (Bain et al., 2011; Callahan and Caughey, 2009).

Derajat histologik karsinoma endometrium merupakan penentu faktor prognostik penting yang dibagi menjadi derajat I-III. Tumor yang berdiferensiasi buruk memiliki derajat yang lebih tinggi dan dengan pola pertumbuhan massa solid non glandular yang tinggi. Tumor yang memiliki derajat yang tinggi mempunyai prognosis yang lebih buruk karena kecenderungannya menyebar keluar dari struktur uterus. Selain derajat histologik, faktor independen utama lain yang menentukan prognosis karsinoma endometrium antara lain umur, kedalaman invasi miometrium, ukuran tumor, invasi limfovaskular dan metastasis ke kelenjar getah bening di rongga pelvis (Hurt et al., 2011). 
Karsinoma endometrium memiliki 4 jalur penyebaran utama, dengan jalur yang paling sering ialah penyebaran langsung ke cervix uteri melalui lapisan miometrium dan lapisan serosa. Demikian pula dengan invasi miometrium yang lebih dalam, sel-sel kanker dapat menyebar melalui sistem limfatik rongga panggul dan kelenjar getah bening para-aorta. Invasi limfatik dapat menyebabkan penyebaran yang sangat luas dengan jalur yang tidak selalu sama. Hal ini yang menyebabkan kesempatan pasien untuk sembuh menurun apabila invasi limfovaskular telah terjadi. Sel-sel kanker yang terlepas juga dapat menyebar dari tuba uterina menuju ke ovarium, peritoneum parietal, dan omentum. Penyebaran hematogen lebih jarang terjadi pada karsinoma endometrium, namun dapat terjadi (Anwar et al., 2011; Callahan and Caughey, 2009).

Prognosis

karsinoma

endometrium bergantung pada beberapa faktor yang berpengaruh seperti stadium, kedalaman invasi miometrium, invasi limfovaskular, derajat histologik. Kedalaman invasi miometrium merupakan gambaran faktor prognostik terpenting karena berhubungan dengan derajat tumor, adanya invasi limfovaskular, dan tingkat kesintasan hidup pasien secara umum. Insidensi metastasis kelenjar getah bening pada karsinoma endometrium meningkat dengan adanya invasi miometrium yang lebih dalam, yaitu dari 3\% menjadi $46 \%$ (Zamani et al., 2012).

Pada penelitian ini dimaksudkan untuk meninjau ulang adanya hubungan invasi tumor ke miometrium dengan invasi limfovaskular dan hubungannya dengan derajat histologik karsinoma endometrium.

\section{Rumusan Masalah}

Berdasarkan latar belakang yang telah diuraikan, masalah yang diangkat dalam penelitian ini adalah untuk mengetahui adakah hubungan invasi miometrium dengan kejadian invasi limfovaskular dan tingginya derajat histologik pada karsinoma endometrium.

\section{Pertanyaan Penelitian}

Apakah terdapat hubungan antara kedalaman invasi miometrium dengan kejadian invasi limfovaskular dan derajat histologik pada karsinoma endometrium.

\section{Metode penelitian}

Penelitian ini adalah penelitian analitik kategorik tidak berpasangan, dengan desain retrospektif. Lokasi penelitian dilakukan di RSUD Tarakan Jakarta Pusat. Populasi yang diambil pada penelitian ini adalah seluruh pasien yang terdiagnosa karsinoma endometrium di RSUD Tarakan Jakarta Pusat pada tahun 2009-2017. Slide kasus yang memenuhi kriteria inklusi dikumpulkan dan dibaca ulang terutama mengenai penentuan grade histologik, invasi miometrium dan invasi limfovaskular.

\section{Analisa Data}

Hubungan antara invasi miometrium dan invasi limfovaskular bila memenuhi syarat Chi Square, dan bila tidak memenuhi syarat menggunakan Uji Fisher (2x2), Kolmogorov Smirnov (2xK). 
HASIL

Dalam penelitian ini total sampel yang digunakan sejumlah 30 sampel, didapatkan usia penderita kanker endometrium terbanyak berusia diatas 50 tahun yaitu sebanyak 18 orang $(60,0$ $\%)$, penderita berusia 30-39 tahun sebanyak 3 orang $(10,0 \%)$ dan penderita berusia 40-49 tahun sebanyak 8 orang $(26,7 \%)$. Jenis kanker endometrium sebanyak 28 kasus $(93,3 \%) \quad$ yaitu adenokarsinoma endometrioid (Tabel 1). Pada penelitian kali ini, didapatkan juga 6 dari 28 kasus adenokarsinoma endometrioid yang berdiferensiasi skuamosa (Gambar 1).

Tabel 1. Distribusi jenis histopatologi kanker endometrium yang ditemukan di RSUD Tarakan Jakarta Pusat (2005-2018).

\begin{tabular}{lcc}
\hline Jenis Tumor & Frekuensi (N) & Presentase (\%) \\
\hline Adenokarsinoma & 28 & 93,3 \\
endometrioid & 0 & 0 \\
Karsinoma musinosum & 0 & 0 \\
Karsinoma serosum & 1 & 3,3 \\
Karsinoma sel jernih & 1 & 3,3 \\
(Clear cell carcinoma) & 30 & 100,0 \\
Karsinoma campuran & & \\
Total & & \\
\hline
\end{tabular}
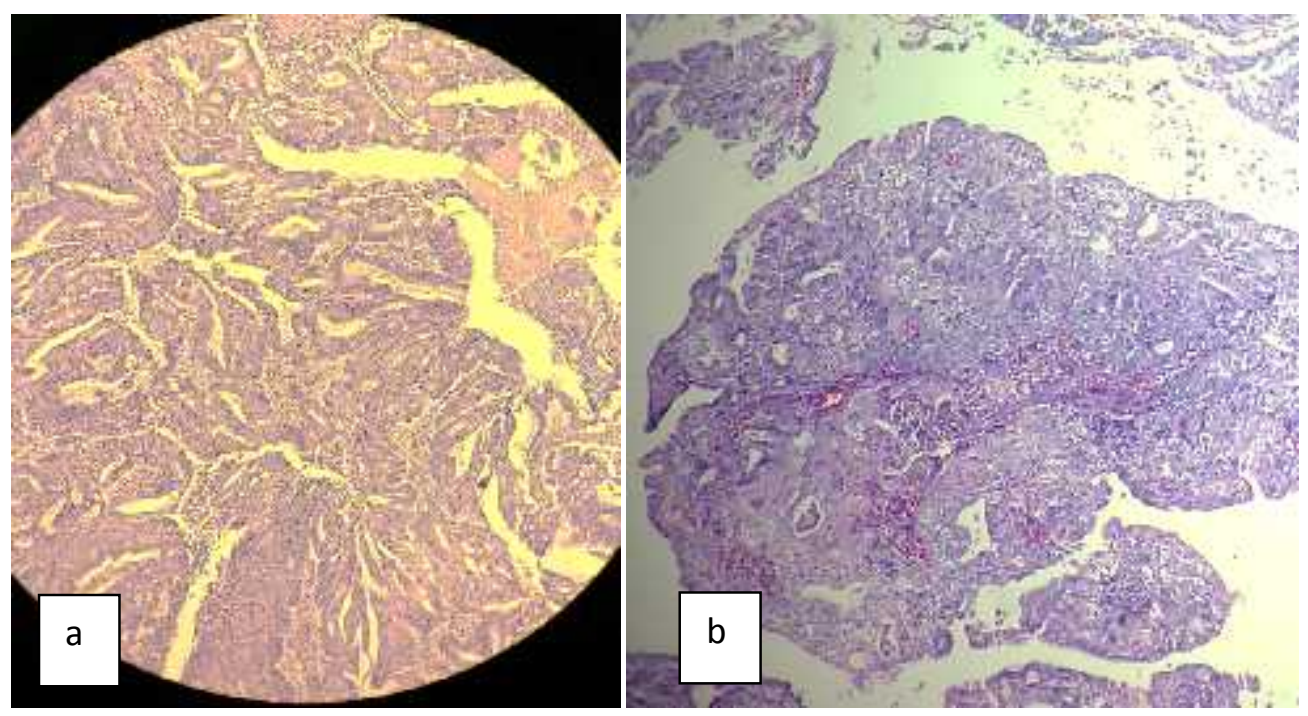

Gambar 1. Gambaran mikroskopis tumor jenis adenokarsinoma endometrioid: a.) Struktur papiler pada adenokarsinoma endometrioid (T130458); b.) Adenokarsinoma endometrioid yang berdiferensiasi skuamosa (T160695). 
Derajat histologik pada kanker endometrium menurut FIGO dibagi menjadi 3 yaitu derajat 1, derajat 2 dan derajat 3. Pada penelitian ini didapatkan karsinoma endometrium dengan derajat 1 sebanyak 12 kasus $(40,0 \%)$, derajat 2 sebanyak 8 kasus
$(26,7 \%)$ dan derajat 3 sebanyak 10 kasus $(33,3 \%)$ (Tabel 2). Kenaikan derajat histologik dikarenakan adanya daerah yang menunjukkan inti pleomorfik dan mitosis ringgi ditemukan pada 3 kasus (Gambar 2).

Tabel 2. Hasil penelitian derajat histologik pada slide histopatologik tahun 20052018 di RSUD Tarakan Jakarta Pusat.

\begin{tabular}{lll} 
Derajat Histologik & Frekuensi $(\mathbf{N})$ & Presentase (\%) \\
\hline Derajat 1 & 12 & 40,0 \\
Derajat 2 & 8 & 26,7 \\
Derajat 3 & 10 & 33,3 \\
Total & 30 & 100 \\
\hline
\end{tabular}

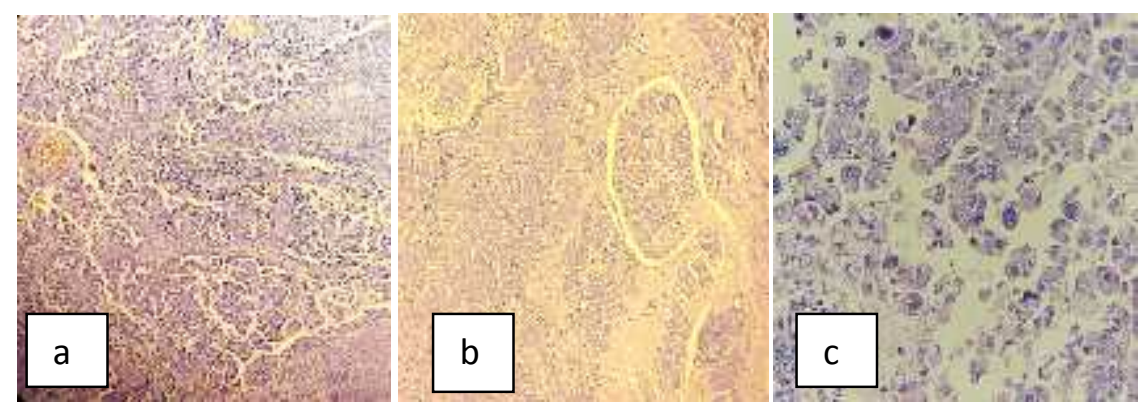

Gambar 2. Hasil pengamatan mikroskopis slide T140464 : a.) dengan pola massa solid $<5 \%$, pleomorfisitas sedang-berat, dan derajat mitosis yang tinggi sehingga menjadi derajat 2; b.) struktur papiler; c) morfologi inti pleomorfik.

Invasi tumor kedalam lapisan miometrium dibagi menjadi 2 kategori yaitu invasi tumor kurang dari setengah ketebalan miometrium dan invasi ke lebih atau sama dengan ketebalan miometrium. (Gordon and Ireland, 2008) Sedangkan, invasi limfovaskular didasarkan pada ada tidaknya emboli massa tumor di pembuluh darah ataupun pembluh limfatik.(Callahan and Caughey, 2009, dos Reis et al., 2015) Pada penelitian ini, karsinoma endometrium yang telah menginvasi kurang dari setengah ketebalan miometrium sebanyak 9 kasus $(30,0 \%)$. Sedangkan 21 kasus lainnya $(70,0 \%)$ telah mengalami invasi tumor ke lebih dari setengah ketebalan miometrium (Tabel 3). Kasus karsinoma endometrium yang tidak mengalami invasi limfovaskular sebanyak 21 kasus (70,0\%), sedangkan kasus yang mengalami invasi limfovaskular sebanyak 9 kasus $(30,0 \%)$ (Tabel 4). 
Tabel 3. Hasil penelitian invasi miometrium pada slide histopatologis tahun 20052018 di RSUD Tarakan Jakarta Pusat.

\begin{tabular}{lll}
\hline Invasi Miometrium & Frekuensi $(\mathbf{N})$ & Presentase $\mathbf{( \% )}$ \\
\hline$<50 \%$ & 9 & 30,0 \\
$\mathbf{2 5 0} \%$ & 21 & 70,0 \\
Total & 30 & 100 \\
\hline
\end{tabular}

Tabel 4. Hasil penelitian invasi limfovaskular pada slide histopatologis tahun 20052018 di RSUD Tarakan Jakarta Pusat.

\begin{tabular}{lll}
\hline Invasi Limfovaskular & Frekuensi $(\mathbf{N})$ & Presentase $(\mathbf{\%})$ \\
\hline Tidak & 21 & 70,0 \\
Ya & 9 & 30,0 \\
Total & 30 & 100 \\
\hline
\end{tabular}

Berikut adalah hasil penelitian mikroskopis adanya massa tumor yang menginvasi lebih dari setengah ketebalan miometrium dan karsinoma endometrium yang telah mengalami invasi limfovaskular (Gambar 3).

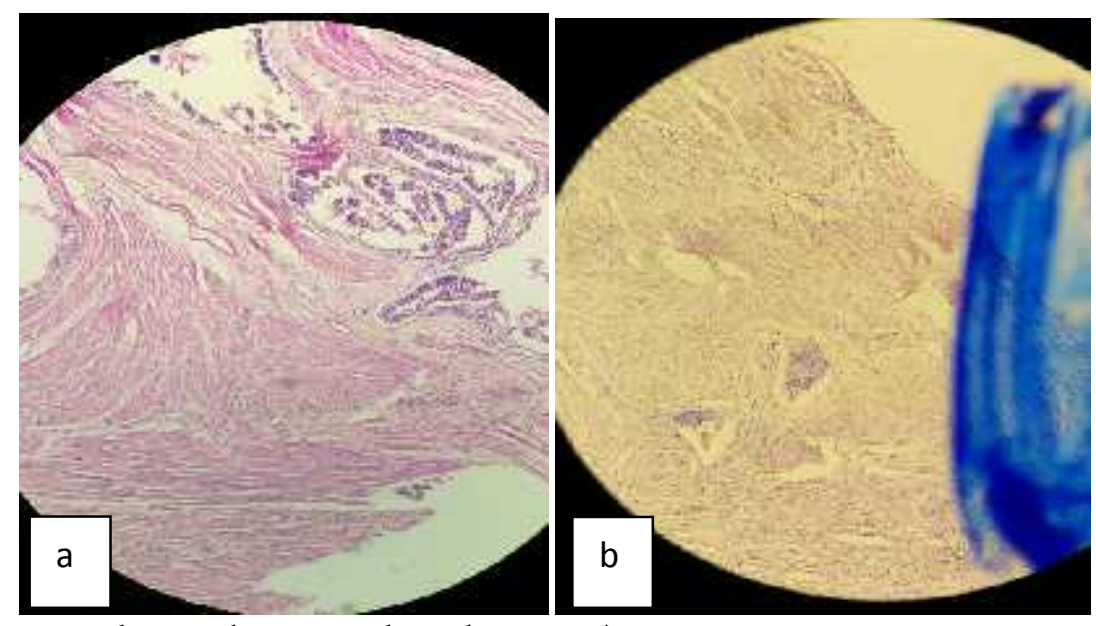

Gambar 3. Hasil penelitian mikroskopis a.) Massa tumor menginvasi lebih dari setengah ketebalan miometrium pada slide T80569; b.) Kanrsinoma endometrium yang telah mengalami invasi limfovaskular pada slide T120424.
Berdasarkan hasil penelitian secara mikroskopis, kanker endometrium yang telah mengalami invasi kurang dari setengah kedalaman miometrium pada kanker endometrium derajat 1 sebanyak 4 kasus $(13,3 \%)$ dan untuk kanker endometrium derajat 3
sebanyak 3 kasus (10,0\%). Sedangkan untuk kanker endometrium yang telah mengalami invasi lebih dari setengah ketebalan miometrium ditemukan terbanyak pada kanker endometrium derajat 1 , yaitu sebanyak 8 kasus $(26,8 \%)$ (Tabel 5). 
Tabel 5. Hasil tabel silang antara invasi miometrium dengan derajat histologik berdasarkan data kanker endometrium di RSUD Tarakan Jakarta Pusat (2005-2018).

\begin{tabular}{lccccc}
\hline & $\begin{array}{l}\text { Invasi }<\mathbf{5 0 \%} \\
\text { Kedalaman } \\
\text { Miometrium }\end{array}$ & $\begin{array}{l}\text { Invasi } \mathbf{z} \text { 50 } \\
\text { Kedalaman } \\
\text { Miometrium }\end{array}$ & Total & p-value \\
\hline Derajat 1 & 4 & 8 & 12 & 0,159 \\
Derajat 2 & 2 & 6 & 8 & \\
Derajat 3 & 3 & 7 & 10 & \\
Total & 9 & 21 & 30 & \\
\hline
\end{tabular}

Pada analisis Kolmogorov Smirnov, hubungan invasi miometrium pada kanker endometrium dengan derajat histologik dibuktikan memiliki hubungan yang tidak bermakna dan didapatkan nilai $\mathrm{p}=0,159$ ( $p$ value > $0,05)$. Hal ini menunjukkan bahwa semakin tinggi derajat histologik kanker endometrium tidak berhubungan dengan terjadinya invasi tumor ke lapisan miometrium.
Kejadian invasi limfovaskular pada karsinoma endometrium terbanyak ditemukan pada slide histologik kanker endometrium derajat 2 yaitu sebanyak 4 kasus (13,3 \%) dari total 9 kasus yang memiliki invasi pada limfovaskular. Sedangkan, pada kanker endometrium derajat 3 ditemukan 7 dari 10 kasus yang tidak mengalami invasi limfovaskular (Tabel 6).

Tabel 6. Hasil tabel silang antara invasi limfovaskular dengan derajat histologik berdasarkan data kanker endometrium di RSUD Tarakan Jakarta Pusat (2005-2018).

\begin{tabular}{lcccc}
\hline & $\begin{array}{c}\text { Tidak Mengalami } \\
\text { Invasi } \\
\text { Limfovaskular }\end{array}$ & $\begin{array}{c}\text { Mengalami } \\
\text { Invasi } \\
\text { Limfovaskular }\end{array}$ & Total & p-value \\
\hline Derajat 1 & 10 & 2 & 12 & 0,637 \\
Derajat 2 & 4 & 4 & 8 & \\
Derajat 3 & 7 & 3 & 10 & \\
Total & 24 & 9 & 30 & \\
\hline
\end{tabular}

Berdasarkan uji analisis Kolmogorov-Smirnov, hubungan antara invasi limfovaskular dengan derajat histologik karsinoma endometrium memiliki nilai $\mathrm{p}=0,637$ ( $\mathrm{p}$ value $>0,05)$. Artinya, semakin tinggi derajat histologik suatu karsinoma endometrium tidak berhubungan dengan kejadian invasi limfovaskular yang ditemukan pada penelitian ini.

Berdasarkan data yang didapatkan, ditemukan sebanyak 9 kasus invasi limfovaskular pada sediaan yang juga mengalami invasi tumor ke lebih dari setengah kedalaman miometrium (30,0\%). Sebaliknya, tidak ditemukan kasus invasi limfovaskular pada karsinoma endometrium yang mengalami invasi kurang dari setengah kedalaman miometrium (Tabel 7). 
Tabel 7. Hasil tabel silang antara invasi miometrium dengan invasi limfovaskular berdasarkan data kanker endometrium di RSUD Tarakan Jakarta Pusat (2005-2018).

\begin{tabular}{lcccc}
\hline & $\begin{array}{c}\text { Tidak } \\
\text { Mengalami } \\
\text { Invasi } \\
\text { Limfovaskular }\end{array}$ & $\begin{array}{c}\text { Mengalami } \\
\text { Invasi } \\
\text { Limfovaskular }\end{array}$ & Total & $p$-value \\
\hline $\begin{array}{l}\text { Invasi }<50 \% \\
\text { Kedalaman } \\
\text { Miometrium }\end{array}$ & 9 & 0 & 9 & 0,029 \\
$\begin{array}{l}\text { Invasi } \geq 50 \% \\
\begin{array}{l}\text { Kedalaman } \\
\text { Miometrium }\end{array}\end{array}$ & 12 & 9 & 21 & \\
Total & 21 & 9 & 30 & \\
\hline
\end{tabular}

Berdasarkan uji analisis secara statistik yang pada kali ini memenuhi uji Fisher's Exact didapatkan hubungan yang bermakna antara invasi massa tumor yang lebih dalam ke lapisan miometrium dengan terjadinya invasi limfovaskular dengan nilai $\mathrm{p}=0,029(\mathrm{p}$ $<0,05)$. Artinya, semakin dalam invasi massa tumor ke lapisan miometrium pada penelitian ini, maka kemungkinan terjadinya invasi limfovaskular semakin tinggi.

\section{PEMBAHASAN}

Distribusi Jenis Tumor dan
Peningkatan Derajat Histologik Pada penelitian ini didapatkan kanker endometrium dengan jenis adenokarsinoma endometrium sebanyak 28 kasus (93,3\%), dengan 6 kasus diantaranya berdiferensiasi skuamosa. Berdasarkan data WHO tahun 2014, adenokarsinoma endometrioid merupakan jenis tersering (70-80\%) yang ditemukan dalam kasus kanker endometrium dengan morfologi yang mirip dengan kelenjar uterus yang normal (Kurman et al., 2014). Struktur papiler (villous) dapat berkembang ke arah lumen uterus, memproduksi musin pada beberapa kasus dan dapat juga mengalami diferensiasi sebagian menjadi epitel gepeng berlapis (skuamosa) yang juga diklasifikasikan menjadi adenokarsinoma endometrioid dengan diferensiasi skuamosa. Tipe ini dapat ditentukan secara pasti ketika terdapat keratinisasi yang abnormal (individual dyskeratotic) dan intercellular bridging (Kurman et al., 2014).

Berdasarkan

International

Federation of Gynecology and Obstetrics(FIGO) pada tahun 1988 dan revisi 2009, skema penentuan derajat untuk adenokarsinoma endometrioid pada endometrium untuk setiap tumor dengan derajat 2 ditentukan dengan adanya komponen massa solid > $5 \%$ hingga $<50 \%$. Atipia inti yang jelas dan derajat mitosis yang tinggi, meskipun tidak sejalan dengan pola pertumbuhan derajat tumor, dapat meningkatkan derajat histologik tumor 1 tingkat dari derajat histologic berdasarkan pertumbuhan tumor (Winham et al., 2014). Hal ini ditemukan pada beberapa slide histopatologik yang memiliki kenaikan derajat histologik tidak sejalan dengan pola derajat tumor ditemukan pada slide T140026, T150481, T181101. 
Kenaikan derajat menjadi 1 tingkat lebih tinggi pada ketiga sampel ini dikarenakan oleh pleomorfisitas inti yang buruk dan tingginya derajat mitosis, meskipun pola pertumbuhan pada ketiga sampel masih cukup baik seperti masih ditemukannya struktur tubular dan papiler.

\section{Derajat Histologik, Invasi Miometrium, dan Derajat Histologik sebagai Faktor Prognostik Kanker Endometrium}

Ada beberapa faktor yang berpengaruh terhadap prognosis pasien berdasarkan stadium patologik yang ditemukan. Secara umum, komponen stadium patologik untuk karsinoma endometrium berupa invasi massa tumor ke dalam lapisan miometrium, invasi ke stroma serviks, maupun invasi ke ovarium ataupun organ lainnya (Kurman et al., 2014). Pada penelitian kali ini, komponen yang dinilai terutama terkait invasi massa tumor ke dalam lapisan miometrium, yaitu $<50 \%$ kedalaman atau $\geq 50 \%$ kedalaman. Invasi tumor ke dalam lapisan miometrium pada karsinoma endometrium terkait dengan penentuan stadium patologik, yaitu stadium 1a dan 1b. Berdasarkan hasil analisis data yang didapat, derajat histologik tidak memiliki hubungan yang signifikan dengan kejadian invasi tumor ke dalam lapisan miometrium dengan nilai $p$ sebesar 0,159 ( $p>0,05)$. Sehingga, berdasarkan penelitian ini derajat histologik tidak dapat mempengaruhi stadium patologik pada kasus karsinoma endometrium.

Derajat histologik yang lebih buruk telah diketahui menjadi salah satu faktor prognostik secara histopatologik untuk kanker endometrium. Namun, derajat histologik tidak dapat menjadi faktor individual yang berpengaruh terhadap kondisi pasien terutama secara klinikopatologis. Hal ini dijelaskan pada jurnal penelitian oleh Singh et al. yang diterbitkan pada tahun 2018, bahwa kanker endometrium telah lama dikaitkan dengan keganasan dengan prognosis yang cukup baik dikarenakan subtipe yang umum ditemukan adalah adenokarsinoma endometrioid dengan derajat rendah (derajat 1) dan dengan stadium yang rendah. Namun, sekitar 20\% kasus dengan kanker endometrium meninggal karena penyakitnya (Singh et al., 2019). Hal inilah yang kemudian menjadi fokus bahwa tidak selamanya kanker endometrium dengan derajat rendah memiliki prognosis yang baik dan sebaliknya kanker endometrium dengan derajat yang tinggi masih mungkin massa tumor belum terlalu invasif. Peninjauan molekular dengan menggunakan marker KI-67 diharapkan dapat dilakukan agar penilaian derajat proliferasi sel tumor menjadi lebih tepat pada karsinoma endometrium, dimana penilaian atypia inti yang melibatkan mitosis dapat menjadi lebih sensitif.

Terdapat faktor-faktor lain yang mempengaruhi penentuan stadium patologik kanker endometrium seperti kedalaman invasi miometrium, invasi ke vagina, permukaan serosa, adneksa, serta faktor independen yang tidak berpengaruh terhadap penentuan stadium namun memiliki risiko metastasis ke kelenjar getah bening dan organ lain yaitu invasi limfovaskular (Kurman et al., 2014). Invasi limfovaskular sebagai salah satu faktor prognostik penting secara patologi berkaitan dengan sifat tumor yang lebih invasif dan berpengaruh terhadap kejadian metastasis ke kelenjar getah 
bening, maupun metastasis jauh secara hematogen (Gaducci et al., 2009). Adanya invasi limfovaskular umumnya berkaitan dengan jenis tumor, derajat histologik yang tinggi dan invasi miometrium yang lebih dalam (dos Reis et al., 2015). Namun, pada hasil analisa statistik yang menyilangkan hubungan antara derajat histologik dan kejadian invasi limfovaskular menggambarkan nilai signifikansi atau nilai $\mathrm{p}=0,637(\mathrm{p}>$ $0,05)$. Artinya, dalam penelitian ini tidak ditemukan adanya hubungan yang bermakna antara peningkatan derajat histologik dengan adanya invasi limfovaskular.

Sebaliknya, invasi tumor yang lebih dalam pada lapisan miometrium meningkatkan kemungkinan kejadian invasi limfovaskular dengan nilai signifikasi 0,029 ( $p<0,05)$. Berdasarkan penelitian yang dimuat dalam "International Journal of Gynecological Cancer" pada tahun 2015, invasi limfovaskular (LVI) dapat meningkatkan risiko terjadinya metastasis kelenjar getah bening. Risiko terjadinya metastasis ke kelenjar getah bening juga diketahui meningkat pada pasien dengan LVI, invasi miometrium yang dalam, keterlibatan serviks, maupun tumor dengan derajat tinggi (dos Reis et al., 2015). Untuk itu, adanya invasi miometrium yang lebih dalam $(\geq$ $50 \%$ harus meningkatkan kewaspadaan bagi klinisi terkait adanya metastasis ke kelenjar getah bening sekitar, maupun metastasis jauh oleh karena kemungkinan adanya invasi limfovaskular.

\section{KESIMPULAN}

Penelitian ini menyimpulkan bahwa terdapat hubungan yang signifikan antara invasi miometrium dengan invasi limfovaskular pada karsinoma endometrium yang memiliki nilai $p=0,029$. Tidak terdapat hubungan yang bermakna antara derajat histologik dengan invasi miometrium $(\mathrm{p}=0,159)$ maupun hubungan derajat histologik dengan invasi limfovaskular $(\mathrm{p}=0,637)$. Dengan adanya penelitian ini, maka hasil biopsi/kuretase yang menunjukkan adanya karsinoma endometrium berapapun derajat histologiknya, tetap harus dipertimbangkan tatalaksana terapi definitif, sehingga penentuan stadium yang mempengaruhi prognosis pasien dapat dilakukan dengan tepat.

\section{KEPUSTAKAAN}

Anwar M, Baziad A \& Prabowo R 2011. Ilmu Kandungan, Jakarta, Tridasa Primer.

Bain C, Burton K \& Mcgavigan C 2011. Ilustrasi Ginekologi, Singapore, Elsevier.

Bieber E, Sanfilippo J, Horowitz I \& Shafi M 2015. Clinical Gynecology, Cambridge, Cambridge University Press.

Callahan T \& Caughey A 2009. Blueprints Obstetric And Gynecology, Philadelphia, Lippincott Williams \& Wilkins.

Disaia P, Creasman W, Mannel R, Mcmeekin D \& Mutch D 2018. Clinical Gynecologic Oncology, Philadelphia, Elsevier.

Dos Reis R, Burzawa JK, Tsunoda AT, Hosaka M, Frumovitz M, Westin SN, Munsell MF \& Ramirez PT 2015. Lymphovascular Space Invasion Portends Poor Prognosis In Low-Risk Endometrial Cancer. Int J Gynecol Cancer, 25, 1292-9. 
Gaducci A, Cavazzana A, Cosio S, Cristofano C, Tana R, Fanucchi A, Teti G, Cristofani R \& Genazzani A 2009. Lymph-Vascular Space Involvement And Outer One-Third Myometrial Invasion Are Strong Predictors Of Distant Haematogeneous Failures In Patients With Stage I-Ii Endometrioid-Type Endometrial Cancer. Anticancer Research 29, 1715-1720.

Gordon M \& Ireland K 2008. Pathology Of Endometrial Carcinoma [Online]. Paula And David Bloomer. Available:

Https://Www.Glowm.Com/Sectio n_View/Heading/Pathology\%20of \%20endometrial\%20carcinoma/Ite $\underline{\mathrm{m} / 238}$ [Accessed November 2nd 2018].

Hurt J, Guile M, Bienstock J, Fox H \& Wallach E 2011. The Johns Hopkins Manual of Gynecology And Obstetrics, Philadelphia, Lippincott Williams \& Wilkins.

Kurman R, Carcangiu M, Herrington C \& Young R 2014. Who Classification Of Tumours Of Female Reproductive Organs, Geneva, Who Press.

Singh N, Hirschowitz L, Zaino R, Alvarado-Cabrero I, Duggan MA, Ali-Fehmi R, Euscher E, Hecht JL,
Horn LC, Ioffe O, Matias-Guiu X, Mccluggage WG, Mikami Y, Ordi J, Parkash V, Quddus MR, Quick CM, Staebler A, Zaloudek C, Nucci M, Malpica A \& Oliva E 2019. Pathologic Prognostic Factors In Endometrial Carcinoma (Other Than Tumor Type And Grade). Int J Gynecol Pathol, 38 Suppl 1, S93-S113. Society AC 2018. Key Statistic For Endometrial Cancer [Online]. Available: $\quad$ Www.Cancer.Org [Accessed October 28th 2018].

Winham WM, Lin D, Stone PJ, Nucci MR \& Quick CM 2014. Architectural Versus Nuclear Atypia-Defined Figo Grade 2 Endometrial Endometrioid Adenocarcinoma (Eec): A Clinicopathologic Comparison Of 154 Cases With Clinical Follow-Up. Int J Gynecol Pathol, 33, 120-6.

Zamani F, Goodarzi S, Hallaji F, Zamiri A, Deilami T, Malek M \& Modarress Gilani M 2012. Diagnostic Value Of Pelvic Mri For Assessment Of The Depth Of Myometrial Invasion And Cervical Involvement In Endometrial Cancer: Comparison Of New Versus Old Figo Staging. Iran J Radiol, 9, 202-8. 